\title{
PERILAKU BULLYING DI SEKOLAH
}

\author{
Rischa Pramudia Trisnani ${ }^{1)}$, Silvia Yula Wardani ${ }^{2)}$ \\ Program Studi Bimbingan dan Konseling \\ Fakultas Ilmu Pendidikan \\ IKIP PGRI Madiun \\ E-mail: rischa pramudia@yahoo.com
}

\begin{abstract}
Abstrak
Penelitian ini bertujuan untuk mendiskripsikan tentang kekerasan atau bullying pada siswa SMP di Kabupaten Madiun. Pada penelitian ini difokuskan pada macam kekerasan yang dilakukan siswa kepada temannya. Subjek penelitian adalah siswa Sekolah Menengah Pertama (SMP) di Kabupaten Madiun bagian selatan tepatnya di Kecamatan Kebonsari. Instrumen penelitian yang digunakan berupa kuesioner. Hasil pembahasan, menunjukkan sesungguhnya perilaku bullying berlangsung di beberapa lokasi di sekolah. Perilaku bullying biasanya terjadi di kelas, kantin atau di toilet sekolah. Bentuk perilaku bullying di SMP 2 kebonsari menunjukkan tindakan bullying verbal langsung lebih banyak dilakukan oleh siswa laki-laki sedangkan bullying non verbal tidak langsung banyak dilakukan oleh siswa perempuan. Disarankan guru meningkatkan pemahaman mengenai bullying, bertindak lebih responsif ketika ada siswa korban bullying, serta sekolah perlu memiliki program preventif maupun program kuratif yang melibatkan semua komponen yang terlibat dalam proses belajar mengajar di sekolah.
\end{abstract}

Kata kunci: bullying

\begin{abstract}
This study aimed to describe violence or bullying in junior high school students in Madison County. In this study focused on the kind of violence done to his students. Subjects were students of Junior High School (SMP) in the southern part of Madison County Kebonsari precisely in the District. The research instrument used a questionnaire. The result of the discussion, showing the actual bullying behavior takes place in several locations in the school. Bullying behavior usually occurs in the classroom, cafeteria or school toilets. Forms of bullying behavior in the Junior 2 Kebonsari show direct verbal bullying is done mostly by male students while the non verbal bullying is not directly carried out by female students. Advised teachers to increase understanding of bullying, act more responsive when a student victim of bullying, and schools need to have preventive programs and curative programs involving all the components involved in teaching and learning in schools.
\end{abstract}

Key words: bullying

Info Artikel

Diterima Desember 2016, disetujui Desember 2016, diterbitkan Desember 2016

\section{PENDAHULUAN}

Dipublikasikan Oleh: Program Studi Bimbingan dan 
Kita sering mendengar terjadi bullying pada remaja. Bullying kadang terjadi di ligkungan sekolah maupun di luar lingkungan sekolah. Sekolah sebagai lembaga pendidikan formal, berfungsi dan bertujuan sebagaimana yang terdapat dalam Undang-Undang No. 20 Tahun 2003 tentang sistem pendidikan Nasional pasal 3 yaitu : Untuk berkembangnya potensi peserta didik agar menjadi manusia yang beriman dan betakwa kepada Tuhan Yang Maha Esa, berakhlak mulia, sehat, berilmu, cakap, kreatif mandiri dan menjadi warga negara yang demokratis serta bertanggungjawab. Untuk mencapai tujuan pendidikan nasional tersebut diperlukan kondisi belajar yang kondusif dan jauh dari kekerasan.

Kekerasan ini dapat dikategorikan sebagai perilaku bullying. Menurut Coloroso (2007) bullying akan selalu melibatkan adanya ketidakseimbangan kekuatan, niat untuk mencederai, ancaman agresi lebih lanjut, dan teror. Bullying berasal dari bahasa Inggris (bully) yang berarti menggertak atau mengganggu. Banyak definisi tentang bullying ini, terutama yang terjadi dalam konteks lain ( tempat kerja, masyrakat. komunitas virtual).Perilaku bullying adalah salah satu bentuk kekerasan dan agresif siswa di sekolah. Bullying bisa berasal teman sebaya, senior atau kakak kelas, dan bahkan guru dan staff sekolah itu sendiri. Sedangkan Tisna (2010:4) mengemukakan bahwa bullying adalah prilaku agresif dan negatif seseorang atau sekelompok orang secara berulang kali yang menyalahgunakan ketidakseimbangan kekuatan dengan tujuan untuk menyakiti targetnya (korban) secara mental atau secara fisik.

Akhir-akhir ini banyak informasi atau berita yang menginformasikan terjadinya kekerasan di sekolah maupun di lingkungan masyarakat. Selain tawuran pelajar terjadi pula kekerasan di lingkungan sekolah. Dan kekerasan tersebut tidak hanya pada sekolah tingkatan atas, melainkan terjadi pula pada sekolah tingkatan SD. Seperti yang diberitakan tentang kekerasan yang terjadi di sekolah diantaranya kasus kekerasan di SDN 07 Pagi, Kebayoran Lama, Jakarta Selatan yang menewaskan siswa A. Selain itu kekerasan yang terjadi di sekolah juga terjadi di SDN Bintara 02, Kecamatan Bekasi Barat, Kota Bekasi. Dalam kasus ini diawali oleh korban yang sering mencemooh pelaku. (Merdeka.com, 12/10/2015).

Kekerasan saat ini banyak terjadi di lingkungan sekolah. Pelaku kekerasan tersebut dilakukan oleh guru, staf sekolah dan siswa. Bentuk kekerasan ini bermacam-macam ada yang berupa verbal maupun non verbal. Kekerasan yang terjadi ini jika dibiarkan akan mempengaruhi psikis siswa.

Terjadinya bullying di sekolah menurut Salmivalli dan kawan-kawan (dalam Ehan) merupakan proses dinamika kelompok dan di dalamnya ada pembagian peran. Peran-peran 
tersebut adalah bully, asisten bully, reinfocer, defender, dan outsider.

a. Bully yaitu siswa yang dikategorikan sebagai pemimpin, berinisiatif dan aktif terlibat dalam perilaku bullying.

b. Asisten bully, juga terlibat aktif dalam perilaku bullying, namun ia cenderung begantung atau mengikuti perintah bully.

c. Rinfocer adalah mereka yang ada ketika kejadian bullying terjadi, ikut menyaksikan, mentertawakan korban, memprofokasi bully, mengajak siswa lain untuk menonton dan sebagainya.

d. Defender adalah orang-orang yang berusaha membela dan membantu korban, sering kali akhirnya mereka menjadi korban juga.

e. Outsider adalah orang-orang yang tahu bahwa hal itu terjadi, namun tidak melalukan apapun, seolaholah tidak peduli.

Riauskina, Djuwita, dan Soesetio (2007) mengelompokkan bullying kedalam 5 kategori:

a. Kontak fisik langsung (memukul, mendorong, mencubit, mencakar, juga termasuk memeras dan merusak barang-barang yang dimliki orang lain).

b. Kontak verbal langsung (mengancam, mempermalukan, merendahkan, mengganggu, memberi panggilan nama (namecalling), sarkasme, merendahkan (put-down), mencela/mengejek, mengintimidsi, mengejek, menyebarkan gosip) c. Perilaku non-verbal langsung (melihat dengan sinis, menjulurkan lidah, menampilkan ekspresi muka yang merendahkan, mengejek, atau mengancam, biasanya disertai oleh bullying fisik atau verbal).

d. Perilaku non verbal tidak langsung (mendiamkan seseorang, memanipulasi persahabatan sehingga menjadi retak, sengaja mengucilkan atau mengabaikan, mengirimkan surat kaleng).

e. Pelecehan seksual (kadang dikategorikan perilaku agresi fisik atau verbal)

Perilaku bullying akan berdampak pada fisik dan psikologis anak. Dampak fisik misalkan tubuh anak memar, terdapat luka dan lain sebagainya, sedangkan dampak psikologis, anak menjadi enggan berangkat ke sekolah, anak cenderung pemalu dan merasa tertekan dengan keadaan tersebut.

Dari penelitian Riauskima dkk mengemukakan ketika mengalami bullying korban merasakan banyak emosi negatif seperti marah, dendam, kesal, tertekan, takut, malu dan sedih). Yang paling ekstrim dari dampak psikologis ini adalah kemungkinan untuk timbulnya gangguan psikologis pada korban bullying seperti rasa cemas berlebihan, selalu merasa takut, depresi, ingin bunuh diri dan gejalagejala gangguan stres pasca trauma (post trumatic stress disoder). Anak yang menjadi korban bullying atau tindakan kekerasan fisik, verbal ataupun psikologis di sekolah akan 
mengalami trauma besar dan depresi yang akhirnya bisa menyebabkan gangguan mental di masa yang akan datang. Gejala-gejala kelainan mental yang biasanya muncul pada masa kanak-kanak secara umum terbukti anak tumbuh menjadi orang yang pencemas, sulit berkonsentrasi, mudah gugup dan takut, hingga tak bisa bicara.

Kegiatan preventif yang dilakukan oleh sekolah juga masih minim. Kadang guru juga tidak mengetahui terjadi bullying di lingkungan sekolah. Masalah ini sangat penting untuk diteliti untuk mengetahui jenis perilaku bullying yang dilakukan oleh siswa, sehingga konselor dapat menyusun program untuk mengurangi bahkan mencegah terjadinya bullying di lingkungan sekolah maupun di masyarakat.

\section{METODE PENELITIAN}

Penelitian ini dilakukan pada siswa SMP Negeri 2 Kebonsari kabupaten Madiun. Penelitian ini menggunakan metode survey deskriptif yang bertujuan untuk menggambarkan fenomena yang sedang diamati. Mengingat banyaknya populasi dalam penelitian ini, maka peneliti mengambil sampel sebanyak $10 \%$ dari jumlah siswa SMP Negeri 2 Kebonsari yaitu berjumlah 70 siswa dengan teknik stratified random sampling.

Instrumen yang digunakan dalam penelitian ini berupa kuesioner.
Kuesioner dalam penelitian ini terdiri dari pertanyaan-pertanyaan yang bersifat tertutup dan terbuka. Pada pertanyaan terbuka, subyek diminta untuk menuliskan pengalaman mengenai bullying yang dialami di sekolah. Pada setiap pernyataan subyek diminta untuk menuliskan satu jawaban dari 2 pilihan yang disediakan, yaitu ya dan tidak.

\section{HASIL DAN PEMBAHASAN}

Penelitian ini bersifat deskriptif, yaitu penelitian yang menekankan pada pengungkapan fakta-fakta menurut kenyataan yang ada. Jenis penelitian ini berusaha untuk memotret kondisi atau situasi dan berupaya untuk mencari jawaban atas pertanyaan "apa", “ dimana", dan "berapa banyak". Dari jawaban - jawaban yang diberikan oleh subyek pada kuesioner, tampak bahwa fenomena bullying juga marak terjadi di kalangan siswa Sekolah Menengah Pertama. Berikut ini adalah hasil temuan di lapangan.

Hasil yang diperoleh dari pernyataan tertutup menggambarkan berbagai variasi perilaku bullying yang terjadi pada siswa Sekolah Menengah Pertama di mana mereka menempatkan diri sebagai korban. Tabel 1 . berikut ini adalah ringkasan dari bentuk perilaku bullying.

Tabel 1. 


\section{Bentuk Perilaku Bullying}

\begin{tabular}{|c|c|c|c|c|}
\hline \multirow[b]{2}{*}{$\begin{array}{c}\text { Variabel } \\
\text { Penelitian }\end{array}$} & \multirow[b]{2}{*}{$\begin{array}{c}\text { Sub } \\
\text { Variabel }\end{array}$} & \multirow[b]{2}{*}{ Deskriptor } & \multicolumn{2}{|c|}{ Jenis kelamin } \\
\hline & & & $\begin{array}{c}\text { Siswa laki } \\
\quad(\%)\end{array}$ & $\begin{array}{c}\text { Siswa } \\
\text { perempuan } \\
(\%)\end{array}$ \\
\hline \multirow{4}{*}{ Bullying } & $\begin{array}{l}\text { Bullying fisik } \\
\text { langsung }\end{array}$ & $\begin{array}{l}\text { Memukul } \\
\text { Mencubit } \\
\text { Menjambak } \\
\text { Mendorong } \\
\text { Mencakar } \\
\end{array}$ & 21,4 & 14,3 \\
\hline & $\begin{array}{l}\text { Bullying } \\
\text { verbal } \\
\text { langsung }\end{array}$ & $\begin{array}{l}\text { Mengancam } \\
\text { Memberi julukan } \\
\text { Mengejek } \\
\text { Menyebarkan } \\
\text { gosip }\end{array}$ & 40 & 25,7 \\
\hline & $\begin{array}{l}\text { Bullying non } \\
\text { verbal } \\
\text { langsung }\end{array}$ & $\begin{array}{l}\text { Sinis } \\
\text { Menjulurkan lidah } \\
\text { Menampilkan } \\
\text { ekspresi muka } \\
\text { yang merendahkan }\end{array}$ & 28,6 & 18,6 \\
\hline & $\begin{array}{l}\text { Bullying non } \\
\text { verbal tidak } \\
\text { langsung }\end{array}$ & $\begin{array}{l}\text { Mendiamkan } \\
\text { seseorang } \\
\text { Memanipulasi } \\
\text { persahabatan } \\
\text { sehingga menjadi } \\
\text { retak, Mengucilkan } \\
\text { atau mengabaikan } \\
\text { Mengirimkan surat } \\
\text { kaleng }\end{array}$ & 10 & 41,4 \\
\hline
\end{tabular}

Dari tabel di atas menunjukkan bahwa siswa yang mendapatkan perlakuan bullying fisik langsung adalah 21,4\% siswa laki-laki dan $14,3 \%$ siswa perempuan, yang mendapatkan perlakuan bullying verbal langsung adalah 40\% siswa laki-laki dan 25,7\% siswa perempuan, bullying non verbal langsung adalah $28,6 \%$ siswa laki-laki dan $18,6 \%$ siswa perempuan sedangkan siswa yang mendapatkan perlakuan bullying non verbal tidak langsung adalah $10 \%$ siswa laki-laki dan $41,4 \%$ perempuan.

Hasil yang diperoleh dari pertanyaan terbuka menggambarkan perilaku bullying yang terjadi pada siswa SMP Negeri 2 Kebonsari menempatkan diri sebagai korban. Hal ini dibuktikan dari jawaban yang peneliti peroleh bahwa siswa SMP Negeri 2 kebonsari sebagaian besar pernah menjadi korban bullying. Bentuk perilaku bullying di sekolah ini 
sudah di jelaskan dalam pembahasan sebelumnya, namun peneliti akan menjabarkan bentuk perilaku bullying lebih rinci.

Tabel 2.

Bullying Fisik Langsung

\begin{tabular}{|c|l|c|c|}
\hline Sub Variabel & Deskriptor & \multicolumn{2}{|c|}{ Jenis Kelamin } \\
\cline { 3 - 4 } & & $\begin{array}{c}\text { Siswa Laki-laki } \\
(\%)\end{array}$ & $\begin{array}{c}\text { Siswa Perempuan } \\
(\%)\end{array}$ \\
\hline \multirow{4}{*}{$\begin{array}{c}\text { Bullying fisik } \\
\text { langsung }\end{array}$} & Memukul & 11,4 & 2,8 \\
\cline { 2 - 4 } & Mencubit & - & 1,4 \\
\cline { 2 - 4 } & Menjambak & - & 5,7 \\
\cline { 2 - 4 } & Mendorong & 10 & - \\
\cline { 2 - 4 } & Mencakar & - & 2,8 \\
\hline
\end{tabular}

Dari tabel di atas menunjukkan bahwa siswa yang mendapatkan perlakuan bullying fisik langsung yang dialami oleh siswa laki-laki yaitu memukul 11,4\%, mencubit tidak ada, menjambak tidak ada, mendorong $7 \%$ sedangkan mencakar tidak ada juga siswa yang mengalami. Bagi siswa perempuang yang menjadi korban bullying fisik langsung yaitu yaitu memukul 2,8\%, mencubit 1,4, menjambak 5,7, mendorong tidak ada siswa yang mengalami sedangkan mencakar $2,8 \%$.

Tabel 3.

Bullying Verbal Langsung

\begin{tabular}{|c|l|c|c|}
\hline Sub Variabel & \multirow{2}{*}{ Deskriptor } & \multicolumn{2}{|c|}{ Jenis Kelamin } \\
\cline { 3 - 4 } & & $\begin{array}{c}\text { Siswa Laki-laki } \\
(\mathbf{\%})\end{array}$ & $\begin{array}{c}\text { Siswa Perempuan } \\
(\mathbf{\%})\end{array}$ \\
\hline \multirow{3}{*}{$\begin{array}{c}\text { Bullying } \\
\text { verbal } \\
\text { langsung }\end{array}$} & Mengancam & 12,8 & 2,8 \\
\cline { 2 - 4 } & Memberi Julukan & 14,2 & 1,4 \\
\cline { 2 - 4 } & Mengejek & 8,5 & 5,7 \\
\cline { 2 - 4 } & $\begin{array}{l}\text { Menyebarkan } \\
\text { Gosip }\end{array}$ & 4,2 & 11,4 \\
\hline
\end{tabular}

Dari tabel di atas menunjukkan bahwa siswa yang mendapatkan perlakuan Bullying verbal langsung yang dialami oleh siswa laki-laki yaitu mengancam 12,8\%, memberi julukan 14,2\%, Mengejek 8,5\%, Menyebarkan gosip 4,2\%. Bagi siswa perempuan yang menjadi korban bullying verbal langsung yaitu mengancam 2,8\%, memberi julukan 1,4\%, Mengejek 5,7\%, Menyebarkan gosip 11,4\%.

Tabel 4.

\section{Bullying Non Verbal Langsung}




\begin{tabular}{|c|c|c|c|}
\hline \multirow[t]{2}{*}{ Sub Variabel } & \multirow[t]{2}{*}{ Deskriptor } & \multicolumn{2}{|c|}{ Jenis Kelamin } \\
\hline & & $\begin{array}{c}\text { Siswa Laki-laki } \\
(\%)\end{array}$ & $\begin{array}{c}\text { Siswa Perempuan } \\
(\%)\end{array}$ \\
\hline \multirow{3}{*}{$\begin{array}{c}\text { Bullying non } \\
\text { verbal } \\
\text { langsung }\end{array}$} & Sinis & 11,4 & 10 \\
\hline & $\begin{array}{l}\text { Menjulurkan } \\
\text { lidah }\end{array}$ & 2,8 & 8,5 \\
\hline & $\begin{array}{l}\text { Menampilkan } \\
\text { ekspresi muka } \\
\text { yang } \\
\text { merendahkan }\end{array}$ & 14,2 & 7,1 \\
\hline
\end{tabular}

Dari tabel di atas menunjukkan bahwa siswa yang mendapatkan perlakuan Bullying non verbal langsung yang dialami oleh siswa lakilaki yaitu sinis 12,8\%, menjulurkan lidah 14,2\%, Menampilkan ekspresi muka yang merendahkan 8,5\%.. Bagi siswa perempuan yang menjadi korban Bullying non verbal langsung yaitu sinis $10 \%$, menjulurkan lidah $8,5 \%$, Menampilkan ekspresi muka yang merendahkan $7,1 \%$.

Tabel 5.

Bullying Non Verbal Tidak Langsung

\begin{tabular}{|c|c|c|c|}
\hline \multirow[t]{2}{*}{ Sub Variabel } & \multirow[t]{2}{*}{ Deskriptor } & \multicolumn{2}{|c|}{ Jenis Kelamin } \\
\hline & & $\begin{array}{c}\text { Siswa Laki-laki } \\
(\%)\end{array}$ & $\begin{array}{c}\text { Siswa Perempuan } \\
(\%)\end{array}$ \\
\hline \multirow{4}{*}{$\begin{array}{l}\text { Bullying non } \\
\text { verbal tidak } \\
\text { langsung }\end{array}$} & $\begin{array}{l}\text { Mendiamkan } \\
\text { seseorang }\end{array}$ & 2,8 & 7,1 \\
\hline & $\begin{array}{l}\text { Memanipulasi } \\
\text { persahabatan } \\
\text { sehingga menjadi } \\
\text { retak }\end{array}$ & 7,1 & 8,5 \\
\hline & $\begin{array}{l}\text { Mengucilkan atau } \\
\text { mengabaikan }\end{array}$ & - & 2,8 \\
\hline & $\begin{array}{l}\text { Mengirimkan } \\
\text { surat kaleng }\end{array}$ & - & - \\
\hline
\end{tabular}

Dari tabel di atas menunjukkan bahwa siswa yang mendapatkan perlakuan Bullying non verbal tidak langsung yang dialami oleh siswa lakilaki yaitu mendiamkan seseorang 2,8\%, memanipulasi persahabatan sehingga menjadi retak $7,1 \%$,
Mengucilkan atau mengabaikan dan mengirimkan surat kaleng tidak ada. Bagi siswa perempuan yang menjadi korban Bullying non verbal tidak langsung yang dialami oleh siswa perempuan yaitu mendiamkan seseorang $7,1 \%$, memanipulasi 
persahabatan sehingga menjadi retak $8,5 \%$, Mengucilkan atau mengabaikan $2,8 \%$ sedangkan yang mengirimkan surat kaleng tidak ada, .

Bullying yang terjadi di kalangan SMP 2 Kebonsari berlangsung di beberapa lokasi disekolah, baik yang dilakukan oleh teman sekelas maupun kakak kelas. Perilaku bullying biasanya terjadi di kelas, kantin atau di toilet sekolah. Korban biasanya mendapat perlakuan bullying saat jam istirahat, ketika ada ulangan pelajaran, dan jam olahraga. Perilaku bullying sangat meresahkan siswa disekolah. Pelaku bullying menunjukkan perilaku yang mengancam, mengolok-ngolok sampai korban bullying menangis, mengancam dan memukul hingga keinginannya dipenuhi.

Korban

bullying

memperlihatkan reaksi yang beragam. Korban bullying biasanya memperlihatkan reaksi ketakutan yang akhirnya menuruti permintaan, melapor ke guru setelah kejadian, minta tolong pada teman dan melapor ke orang tua. Hal lain yang ditemukan pada penelitian ini adalah terbukanya peluang bagi siswa untuk menjadi pelaku bullying. Hal ini dibuktikan dengan adanya tindakan yang membuat siswa menjadi takut berangkat ke sekolah karena sering di ejek nama orang tua nya, dipaksa ikut membolos dan dipaksa untuk mencuri jajan di kantin sekolah.

Hasil penelitian pada siswasiswi SMP Negeri 2 Kebonsari teridentifikasi bahwa tindakan bullying verbal langsung lebih banyak dilakukan oleh siswa laki-laki sedangkan bullying non verbal tidak langsung banyak dilakukan oleh siswa perempuan. Siswa yang menjadi korban bullying biasanya memiliki kekurangan atau perbedaan baik secara fisik ataupun materi, siswa yang tidak mau melakukan apa yang diperintahkan oleh pelaku bullying, siswa yang tidak bisa membela diri, siswa yang kesulitan dalam bergaul, serta siswa yang mengalami kesulitan berkonsentrasi dalam mengikuti pelajaran.

Perilaku bullying merupakan tindakan yang sangat berbahaya dan tidak boleh ditiru karena membawa dampak traumatik luar biasa yang dapat mempengaruhi kehidupan anak ataupun remaja pada tahap perkembangan selanjutnya. Perilaku bullying harus segera di hentikan meskipun dalam mewujudkannya membutuhkan bantuan dari berbagai elemen pendidikan seperti guru, siswa sendiri, keluarga dan seluruh staf sekolah, sehingga bullying tidak disikapi sebagai suatu tindakan wajar dan bukan bentuk dari penyiksaan yang menimbulkan korban.

\section{SIMPULAN}

Bullying adalah perilaku negatif seseorang atau sekelompok orang yang dengan sengaja menyakiti targetnya (korban) secara mental atau secara fisik. Perilaku bullying ini bisa 
dicegah selama semua yang terkait dalam institusi/sekolah tersebut memiliki andil dan kepedulian untuk mengubah dan mencegah persoalan tersebut. Perilaku bullying di sekolah dapat dicegah dengan adanya kerjasama antar anggota warga sekolah, meliputi kepala sekolah, guru dan siswa.

Perilaku bullying di Sekolah Menengah Pertama (SMP) biasanya terjadi dalam bentuk bullying verbal dan bullying non verbal secara tidak langsung. Pihak sekolah harus segera menghentikan segala bentuk perilaku bullying meskipun dalam mewujudkannya membutuhkan bantuan dari berbagai elemen pendidikan, sehingga bullying tidak disikapi sebagai suatu tindakan wajar dan bukan bentuk dari penyiksaan yang menimbulkan korban, karena bullying dapat berdampak pada fisik maupun psikis/psikologis korban bullying.

\section{SARAN}

1. Guru sebaiknya meningkatkan pemahaman mengenai bullying sehingga dapat mengetahui, mencegah dan menangani bullying secara dini.

2. Guru harusnya bertindak lebih responsif ketika ada siswa yang dibully serta memberikan bimbingan dan pengarahan kepada korban, pelaku, dan pengamat.

3. Sekolah perlu memiliki program baik program pencegahan maupun program intervensi pemulihan yang melibatkan semua komponen yang terlibat dalam proses belajar mengajar di sekolah.

\section{DAFTAR PUSTAKA}

Ariesto, Asdrian, 2009, "Pelaksanaan Program Antibullying Teacher Empowerment Program (TEP) Di Sekolah (Studi deskriptif program Teacher Empowerment Program bagi guru di SMA "X”: Jakarta Selatan", Skripsi S-1 Fakultas Ilmu Sosial Dan Ilmu Politik, Jakarta: Universitas Indonesia.

Colorosa, B, 2007, Stop Bullying (Memutus Rantai Kekerasan Anak dari Prasekolah Hingga SMU), Jakarta: Ikrar Mandiri Abadi.

Ehan, 2014. Bullying dalam Pendidikan. http://file.upi.edu/Direktori/FIP/J UR. PEND. LUAR BIASA/195 707121984032EHAN/BULLYING DALAM P ENDIDIKAN.pdf. 3 Agustus 2016.

Riauskina, Intan Indira., Djuwita, Ratna., Soesetio, Sri Rochani. 2005. "Gencet-Gencetan" Di Mata Siswa/Siswi Kelas I SMA : Naskah Kognitif Tentang Arti Skenario, dan Dampak "Gencet-Gencetan". Jurnal Psikologi Sosial. Volume. 12. Nomor.01, September. Fakultas Psikologi Universitas Indonesia.

Rudi, Tisna. 2010. Informasi Perihal Bullying.Ebook. Diakses bulan Maret 2015 https://www.merdeka.com/perist 
iwa/usai-dihina-burik-olehteman-kepala-siswi-sd-di-

bekasi-diduduki.html. 
